\title{
ReOrienting the World System
}

Robert A. Denemark

University of Delaware

denemark@udel.edu

Barry K. Gills

University of Helsinki

Barry.Gills@helsinki

We can begin by accepting Bergesen's call for a new model that better represents the "distinctly 'political' economy" of the actual world and the prominent role of the "political/military component" in its overall structure. This is very much in the spirit of Frank's work in Reorienting the $19^{\text {th }}$ Century. We also share much agreement with Bergesen's critique of Wallersteinian or "Standard World-System Analysis" (hereafter SW-SA), including several points of criticism Frank and others have made in the past, when developing an alternative world system (without a hyphen) history (Abu-Lughod 1989; Frank and Gills 1993; Denemark et al. 2000). It is unfortunate that Bergesen does not reference this previous research examining centuries and even millennia of what Bergesen calls "historically conserved trade structures" in world system history.

Bergesen also makes a further call, for "a new understanding of the role of intercontinental trade as the essential relation of the world economy." We would amend this by saying that although "trade" on an inter-continental scale is a constant, and in fact, a constituent feature of world system structure (for five millennia), and it is true that trade may be the essential mechanism of the world system, it is misleading to call trade the essential relation. The essential relation is rather that of "accumulation" of wealth, capital, and power within the world system. The pursuit of this accumulation affects the overall pattern of trade (as a cause to an effect) while also shaping "systemic relations between societies" as Bergesen puts it.

In regard to Bergesen's critique of the role of the "capitalist mode of production" in SWSA, we would agree that the capitalist mode of production in itself does not adequately account for the origins of the modern world system. We also agree that "capital" pre-dates the modern economy. However, in today's world, the form "capital" and social relations based on the capitalist mode of production have extended and deepened to an historically unprecedented degree.

We must disagree with Bergesen's assertion that "there is no way to move theoretically from relations between whole zones of the world to relations between classes within a zone." World System history (without a hyphen) has from its earliest formulations (e.g. Gills and Frank 1990) indicated that a structure of inter-class relations exists in a world system, based on the "inter-penetrating accumulation" between different zones of the world system. These inter-class structures both extend beyond the borders of any formal political entities and significantly influence the pattern of class relations within political entities. "Accumulating and expanding

This work is licensed under a Creative Commons Attribution 4.0 United States License. Journal of World-Systems Research, Volume 21, Number 1, Pages 193-202, ISSN 1076-156X 
overseas" have been linked for millennia in world system history, including previous "waves of expansion" (or "pulsations"), linked to imperialist logics and rivalries, as well as periodic "world system crises," long before the late $19^{\text {th }}$ century example, or even the long $16^{\text {th }}$ century.

There are four issues Bergesen raises that we wish to engage in greater detail.

\section{A. Capitalism, Trade, and Multilaterality}

Bergesen offers Frank's multilaterality, together with his own concerns regarding the rise and various interactions of trade-based hegemonic states, as a palliative to what he identifies as the now-tired analysis of capitalism, the SW-SA focus on "production for exchange," and lack of attention to inter-core rivalry and strategic interaction.

As regards Bergesen's critique of an overemphasis on capitalism and the capitalist mode of production in SW-SA, we recall that Frank generated a firestorm by questioning the primacy of "capitalism." Frank's first "ReOrientation" (1998) generated a special issue of Review with articles by Wallerstein, Arrighi, and Amin, that mostly aimed at attacking the alleged error of Frank's abandonment of the concept of "capitalism" as the motive force of the modern worldsystem. This was ironic. Four decades ago world-systems analysis took its most critical blows from traditional Marxists who argued that in ignoring capitalism as a totalizing mode of production, and treating it incorrectly as merely part of a system of global interaction, worldsystem scholars had committed the sin of "Smithianism" (Brenner 1977): i.e. allegedly focusing on "the sphere of exchange," and thus supposedly ignoring class relations. Wallerstein argued (correctly) that "capitalism" could and should be understood as the motive part of a European system that did not however preclude the use, preference, or even creation and codification of "pre-capitalist" forms elsewhere. Capitalists in the core were happy to use, facilitate, or create any social formation that helped accumulate capital (slavery and the feudal relations of the demesne or plantation are prime examples).

Where Wallerstein argued that "non-capitalist" forms could be part of a "capitalist" system, SW-SA analysis now argues that capitalist forms cannot be part of a broader system. Frank's use of a more inclusive concept of "modes of accumulation" (Gills and Frank 1990) was criticized for lack of fidelity with traditional beliefs in the primacy of the capitalist mode of production. Frank argued that there are overarching modes of accumulation; that "capitalism" may be part of such a mode; that it may exist in some areas and not others; and, that it may play alternatively larger or smaller roles. By starting from a Eurocentric historical perspective we make the error of attributing everything to "capitalism," and thereby fail to see earlier, different, variegated, and longer-lived systems of accumulation. Frank's adoption of a focus on 5,000 years of world system history (without a hyphen), his sustained interest in the role of Asia, and his calls for humanocentrism to supersede the intellectual legacy of Eurocentric analyses ought not to fall on deaf ears.

To put the argument about multilateralism in context, we must remember that Frank was trained as an economist at the University of Chicago and fought several battles with former colleagues there and elsewhere about how to understand and interpret trade. His arguments on the methodological importance of a multilateral perspective can be traced back to articles he wrote in the 1970s in the midst of these debates and emerged while he was engaged in an argument about the benefits of imperialism to the imperial countries themselves. Bilateral trade figures did not show that the imperialist powers earned more than they spent in the bargain. Frank thought this was absurd, and set about explaining the multilateral logic of imperialist 
processes (Frank 1979). Frank's mature global systemic multilateral perspective, as demonstrated masterfully in ReOrienting the $19^{\text {th }}$ Century, is a most profound insight.

Bergesen suggests that Frank's analysis, which he hopes to build upon, must undercut the Wallersteinian argument about "production for exchange" as the key process mediating worldsystem relations. We do not believe this is the case. Trade, regardless of its "laterality," has never been exclusively about profits. Rather, it has always also been about the form and range of sociopolitical and economic development that different specializations and production processes, and terms of trade, may generate. Bergesen offers some ideas about the multilateral/angular trade system as a combinatorial system, capable of infinite (re)combinations, and suggests that trade structures and their "triangles" are "highly conserved" historically. This implies that trade triangles are the basic structure of the world-system, that we have always had them, and that they play a similar role and maintain a similar operational logic across historical contexts. If these triangles can be identified in even earlier periods, they may supplant "production for exchange" as a foundation for world system formation, and we might then look at related processes like transport, military control or protection, and commercial services, as was already suggested by Abu Lughod (1989) and others, and pursued by Frank in ReOrienting. World-systems studies have included any number of analyses of incorporation, change, commodity chains, rise, and decline within the confines of the world-economy, but have not yet systematically considered trade triangles. Yet such triangles offer a glimpse into the generation of great wealth, and constitute a guide to when and where force is being used (e.g. to depress wages, extort tribute, decrease competition), as well as where cultural forms are being imposed, propped up, or subverted. This is surely an oversight, but not a necessary one.

Bergesen argues that SW-SA ignores the fact that "capitalist hegemons" have all been sea powers because it is insufficiently concerned with inter-core rivalries. However, one of the key cyclical processes of the original formulation of world-systems analysis is specifically "hegemony-rivalry," which fits exactly into the hole that Bergesen suggests exists. Worldsystems analysis has not ignored geopolitical rivalry and conflict, although the relation of much of this analysis to the narrow "realist" school of traditional U.S.-dominated international relations remains quite highly problematic.

\section{B. Core-Periphery Hierarchy and Emphasis}

To point out that the core oppressed the periphery, to suggest that this (more than anything else) defines the hierarchy so emblematic of the modern world-economy, and to trace the mechanisms of that oppression via the logic of capitalism was enlightening and path-breaking 40 years ago. Ideologically and practically, the core-periphery focus was logical in that it spoke to one of the key issues of the day in a way that shed more light than previous, painfully ideological treatments had done. This signaled a move forward. Is it now passé? Has it become a detriment, as Bergesen claims, in an era when powerful forces of ideological control (e.g. politicians, policy-makers, media, and economists), repeat the "big lie" about "developing countries," even though it is clear that their analyses of "take-off," "efficiency," "marketization," "adjustment," "free trade," and "globalization" are either fallacious or self-servingly ideological. Even students appear to be losing interest in oppression and solidarity. Colleagues adopting the latest methods do not offer us a theoretical understanding or empirical account of the materialstructural sources or foundations of oppression, nor do they appear to wish to do so. Tellingly, the current Pope cannot call for an emphasis on the poor without the political right informing 
him that his doctrinal interpretation is essentially Marxist and seeking to vilify him as a result (Odone 2013). Bergesen argues that we should focus our analysis elsewhere.

We offer two retorts. First, we contend that SW-SA does not need to be stuck in the rut of post-dicting an oppressive core-periphery hierarchy. While hierarchy is indeed a defining element of the system, various cyclical processes (e.g. hegemony-rivalry; economic expansioncontraction; advantages to capital over labor), its secular trends (e.g. commodification, mechanization, expansion), and the "three legged stool" (i.e. politics/economics/culture) may grant more latitude to scholars than Bergesen suggests. Bergesen may be correct about what is going on in the "traditional" world-systems literature, but there are more options available even within SW-SA.

Second, and more critically, Frank's position would have us look at the core-periphery hierarchy and the oppression that is embodied in it, and inter-core rivalry and the geostrategic processes that are embodied in it, as part of the same unified global process. We take issue with Bergesen's argument, which essentially amounts to "kicking the periphery back out" of our analysis. We contend that the rise to great power status is intimately related to the oppression of the periphery. If SW-SA was overly focused on the oppression side of the equation, Bergesen would seem to us to suggest that we overly focus on the other. Neither is optimal. The two processes cannot be separated.

Frank's formidable empirical analysis emphasizes the hierarchical nature of the structure of the world system as a whole throughout the $19^{\text {th }}$ century (and beyond). One key aspect of this hierarchical global structure resides in the asymmetric relations constructed between states, where the most powerful dominate the vulnerable or less powerful "parts" (states) of the system. He consistently indicates the importance of the pro-active role of certain states and the elite who govern them. He illustrates this state role in the process of industrialization itself, using examples from Japan, the USA, and Germany, as well as numerous state-led attempts at "defensive" or "self-strengthening" measures undertaken by non-Western countries. Here Frank's analysis shows that the capacity of a state to successfully industrialize and develop depends on its position in the whole system. A weak position creates a lower probability of success in industrialization, while the stronger the position becomes, the more probable the success of industrialization. Frank notes emphatically that "states made nations" and not vice versa, and he seems to imply that states created nations as part of a project of the "national" elite's pursuit of increased wealth and power, and the quest for a stronger position in the world system (to the same end).

Frank repeatedly stresses the globally pivotal role of the "Home Charges" (basically a form of "tribute") levied by the British state upon (the peasant masses of) India, and especially stresses its link to the UK's ability to create and hold the position of apex in the multilateral global system as a whole. He emphasizes again and again the policies of "imperialism" practiced by European states and somewhat later by America. Frank argues that imperialist policies were designed precisely to weaken other targeted states in the world, and in particular their capacity to conduct autonomous economic policies in a robust defense of national economic sovereignty, exercise genuine independence from foreign influence or intervention, or pursue strategies of state-led industrialization and national capital formation. Moreover, he analyzes examples of how some powerful states of the West intervened in the domestic political, class, and ideological contests within other countries, with the intention to obstruct the power of "nationalist" industrializing elites and their preferred policies, while simultaneously supporting and empowering those who favored economic "openness" and "free trade," and were otherwise 
willing to play a comprador role vis-a-vis metropolitan imperial interests. He argues that these interventions often tended to benefit mainly the landed class and their commodity export interests, at the expense of national industrial strategy and economic diversification out of dependence on (primary) commodity exports.

Indeed, Frank's analysis empirically investigates and chronicles the processes by which the "privileged" positions and the "underprivileged positions" were constructed historically in the 19th century. His conclusion recapitulates his insights from Dependency theory-i.e. that the role of the underprivileged positions in the system "is to transfer wealth and income to the privileged ones through the structure and operation of this multilateral/angular system" (Frank 2014: 89). For those at the apex (UK in the 19th century), "this position of greatest privilege... accounts for most of its wealth and income" (ibid). Frank explains that this multilateral/angular global structure "permits those at angular systemic locations of privilege to exact tribute or rent from the system as a whole and in particular from those in under-privileged positions" (ibid; also cited in Bergesen). We can thus concur with Bergesen's statement that "It is power plus exchange, then, which creates the inequity of wealth extraction" and that the apex position is "politically underwritten" in a global shell game of capital accounts and transfers in which the capital of the poor(est) is used to enrich the rich(est) through several mechanisms, including "foreign (sic) investment." Bergesen's final quotation from Frank's ReOrienting again recapitulated Dependency theory insights, wherein Frank argues that the systemic consequence of the crisis following 1870 was to consolidate not only the multilateral/angular structure itself, but moreover "the ultimate placement of Asia, Africa, and Latin America in structural positions of disadvantage, nay, of systemic exploitation and often oppression that generated the development of underdevelopment with a vengeance" while simultaneously allowing those in privileged positions to "derive their income" and "to dissipate entropy that was generated to what then became the third world" (Frank 2014: 73). Numerous interventions by powerful imperialist states tended to further "retard" and distort the course of their development and their economic and social structure.

Frank extends his discussion to the colonial state as a special category. He refers to the purposes of globally powerful states to construct colonial and neo-colonial states in the regions under their domination. Frank argues that the real purpose of these colonial states was to bring about the right conditions for the creation of (permanent) export surpluses from the subordinate areas of the global system to the imperial states, and thus to be a mechanism to support the development of the metropolitan centres. Indeed, he argues that it was (and is) this mechanism of the export surplus (from the underdeveloped to the developed) that is the primary way to actuate the systematic transfer of value from the economies of the poor and subordinated to those of the rich and powerful. Frank also stresses the importance of another mechanism, however, which he implies may have been then (as now) the supreme instrument of control over the "Third World." That instrument is debt, which is a device that facilitates the acquisition of foreign control over subordinated economies, as well as a concrete vehicle for the systematic transfer of wealth from the poorest to the richest zones of the world system. "Free trade" policies between the dominant powers and the non-Western world are revealed by Frank to be asymmetrical in both design and effect, being a very useful instrument to promote the interests of the advanced industrialized economies, who benefit hugely from such policies, at the expense of those in subordinate positions in the international division of labor and the multilateral system of trade and payments (im)balances. 
The positions (or "LOCATIONS") created during the $19^{\text {th }}$ century, once established, have proven to be very difficult to alter, but not impossible. The specific roles "assigned" to subordinated areas during the $19^{\text {th }}$ century, in the international division of labour, the specific composition of commodity production, historically conditioned levels of state capacity, and particular class and socio-political characteristics, vary considerably across countries and regions. But none of these elements necessarily permanently precludes the possibility of conducting counter-strategies for self-strengthening or industrialization-i.e. strategies to attempt to change position in the world system and "ascend" within its hierarchical structure. Otherwise, it would not be possible to understand the development of Japan, beginning in the later part of the $19^{\text {th }}$ century, nor the contemporary industrial and economic development of several Northeast Asian states, including China. ReOrienting the $19^{\text {th }}$ Century includes extensive analysis of and reference to the "industrious revolution" path to industrialization, formulated by Sugihara, upon whom Frank largely depends for this understanding. Let it suffice to point out that in this schema of an alternative pattern of non-Western industrial development, the role of the pro-active state remains a pivotal aspect to its design and ultimate success. Overall, Frank's message to us may be that the global political economy of the world system is probably more politically organized than present day conventional understandings tell us-i.e. in reality "politics" is more the "cause," and "economics" is more the effect than the other way around. It is in this context that we might better understand Frank's most controversial statement in ReOrienting the 19th Century, which emerged in at least three different draft chapters (as he sought for the right place to put it), and bears quoting here:

Without trying by any means morally to justify or politically to support any and all imperialism and colonialism nor any of its consequences, the time has come to review and where appropriate to revise the substantially ideological dogma of Western triumphalism over alleged 'traditionalism' elsewhere and simultaneously of much of the nationalist appeal to and 'defenses' of 'traditional' values and also its exaggeration of the deformation of 'third world' economies. To do so in no way negates the critique of ideologically inspired classical, neoclassical, and Keynesian 'scientific' analysis and political propaganda by dependence and world-systems theory and their alternative analyses. The reexamination of reality and its still other alternative analysis proposed below may also parallel the denunciation of the received wisdomof both now 'traditional' and the new dependence as well as world-systems analysis by their denunciation by recent postmodernist, postcolonial, and subaltern textual 'analysis' as far as the latter go, which is not much (41-2).

These were difficult sentiments for Frank to express, but he clearly felt they were necessary. The rise of China, (the possible) rise of India, and several other issues, led Frank to reassess the saturation and historical staying power of oppression. Horrible in every respect, colonialism was nonetheless less pervasive, or perhaps peripheral populations were more resilient, (or both) than Frank believed that he and others had predicted. It was going to be vital to study the dynamics of that process all over again, and to do so carefully so as not to wander into the trap that would be set by apologists who hope to set us toward the conclusion that "colonialism was not that bad." Unfortunately, Frank knew he would not live to engage in that battle.

In summary, states' imperialist policies were a central feature of the global politics of inter-core rivalry and the rise to hegemony in the $19^{\text {th }}$ century, in the construction of its particular 
global hierarchical structure, and of "the development of underdevelopment." The "positions" created by those powerful states, and the inferior positions imposed upon the "weak" during the $19^{\text {th }}$ century have had long lasting historical consequences, including in the present. Frank implies the thesis that it was primarily the exercise of state power, by force and manipulation, and not "market forces" operating independently and "freely," that most determined the course and the historical outcomes of the $19^{\text {th }}$ century world system. The role of the state was pivotal to the whole system's ultimate shape and character. Perhaps this is as true now as it was in the $19^{\text {th }}$ century. We suspect Frank would probably agree with that assessment.

\section{On Bringing the State Back In}

Bergesen's concern with inter-core rivalry resonates with another of the big questions raised by Frank. What explains the fact that Britain ended up at the pinnacle of the triangles that afford such great power and wealth? Bergesen is right in his desire to extend our analysis of the political substructure of core rivalry and hegemony. Frank argued that LOCATION in the world system is not a function of the liberal market or fidelity thereto, nor is it in any way permanently fixed. ReOrienting the 19th Century chronicles the long historical ascent of Great Britain to the pinnacle of the system (of which Britain was largely a creator on a global scale). Subsequently, Frank assesses the long relative descent of Great Britain, accompanied by the ascent of competitors, and the miseries of myriad subordinated and colonized peoples around the world as a result. This analysis of ascent and descent extends to the present era. It includes the relative (re)ascent of East Asia and China, and other contemporary "emerging economies." Frank also gives attention to the prospect of the relative descent of the United States, the inheritor to Britain's pinnacle position after the end of the Second World War.

Thus, Frank's repeated mantra of "LOCATION>LOCATION>LOCATION" needs to be interpreted as historically changing. This recognition however, implies the necessity to examine specific strategies and economic policies, the domestic and international composition of forces, and many other factors, that over time account for either a successful historical trajectory of ascent, or one of descent, within the hierarchical structure of the global political economy. This analysis should also include the nature and effects of the "position maintaining strategies" pursued by the already very powerful states, as well as the nature and outcomes of any counterstrategies and counter-alliances that may be formed against the dominant powers' interests. Let us recall that Frank examines the position-maintaining strategies pursued by a declining Britain in the later $19^{\text {th }}$ and early $20^{\text {th }}$ centuries, explicitly acknowledged by British elites to be designed to maintain Britain's privileged position in the global system, even at the direct heavy human cost of subordinate peoples, most especially in India.

The $19^{\text {th }}$ century world system culminated in a brutal round of violent colonial expansion and inter-imperialist rivalry on a global scale, with increasing militarism and intensive arms races, and eventually two world wars and a global depression during the first half of the $20^{\text {th }}$ century. Frank traces this modal shift to the systemic effects of the economic crisis that began in 1873. He links this to the final or real "fall of the East" after 1870 (a key argument throughout the book) and the final consolidation of the multilateral trade and payments system of (im)balances and entropy dissipation. During this several decade period, the British state was joined by the U.S., Germany, and France at the apex position in the global political economy, soon to be emulated and joined by Japan. 
But all of these machinations beg the question of how England (or any other actor) might first construct such a system. Frank titled his (unwritten) concluding chapter "Bringing the State Back In" and this appears to be what Bergesen wants to do with his emphasis on state action in the context of inter-core rivalry. The state must play a role, and nowhere is this more important than in core states that find themselves at a disadvantage they must overcome, or peripheral states that choose to pursue strategies that are at odds with their continued exploitation. But ought we assume that there was some explicit state-led policy that generates the architecture of hegemony? Frank always argued that policy was never about what it claimed to be about, nor did it tend to have the impact it was expected to have, in any event. In the case of England it appears that a basket of decisions and non-decisions by the state, as well as by explorers, piratical naval captains, chartered companies, and rogue bureaucrats, all played important roles. Such actions cumulated in ways we do not yet fully understand into some global level advantages that were built upon and became positively self-reinforcing. Some of it was likely the fact that other powers were not in positions to impose their wills on England. England made its own way within the sets of incentives and disincentives that the global system offered, and ended up on top. How much of this was foresight, or a confluence of public and private interests, or a freedom from the imposition of the plans of others, or a matter of dumb luck? Perhaps a position at the pinnacle of the system is partly the result of being a wealthy sea power, as Bergesen suggests, and partly the result of being sufficiently brutal enough and/or lucky enough to collect the correct puzzle pieces such that by happy coincidence they fit together in just the right way. Bergesen is correct when he suggests that we need to pay more attention to this dynamic.

We might gain some insight by building on the world system literature on cycles of hegemony and rivalry. William Thompson's work on innovation and leadership might provide part of the answer. Perhaps part of the answer rests with competitive imperialisms and the tendency for the world-system to engage in systemic war on a fairly regular basis. Building on the hegemony-rivalry literature, Wallerstein (and a number of others both within and outside of world-systems analysis) suggested that there would be a "war peak" (a period when the chance of global war would be highest) between 2030 and 2050 (Pollins 1996; Denemark 1999). This is not nearly as far off as it was when these works were first published, and certainly the dangers of hegemony-rivalry are becoming more apparent once again and should not be underestimated. The interactions of the dynamics of multilateral trade and payments triangles (and the global dissipation of entropy) and their relationship with systemic or global war, as Bergesen argues, is both a very timely and a most important future research focus.

\section{Environment and Entropy}

Finally we come to the question of the natural environment, which neither Bergesen nor anyone else should ignore. Frank considered this to be one of the most important potential contributions of the book, but sadly it was also the least developed. The quest for resources, from rare earths to shale oil, and in the not-so-distant future the quest for breathable air and drinkable water, will likely generate significant inter-core rivalry. Sensitized by the insightful work of Sing Chew, with whom he interacted regularly (despite his illness, Frank read and commented upon the draft manuscript of Chew's important study The Recurring Dark Ages: Ecological Stress, Climate Changes, and System Transformation, which was published after Frank's death), Alf Hornborg, and later Mike Davis, Frank came to the conclusion that the infrastructure of all living processes was something we had ignored. His work on this issue 
betrayed his fierce desire to dive into an important topic about which he initially knew so little. This relationship includes the absorption of negative entropy by the poorer countries and regions of the world, generated by the development of the industrial countries.

Though he was unable to complete his analysis of the role of entropy, he gives us indications that the deleterious and long term effects of this type of structural violence extends to the export of "disorder" as well as of environmental degradation and pollution. His analysis provokes us to investigate the global uneven distribution of negative entropy, both social and environmental, as an engrained feature of the global system. Its full story in the development of underdevelopment and in the production of global poverty and inequality is yet to be told.

Bergesen's essay is a vivid admixture of homage, critique, and reformulation. It draws on vital elements of Frank's work, and offers us yet more. It challenges traditional worldsystems analysis to broaden itself, it challenges Frank's colleagues, who were part of the intellectual traditional that led to his ReOrienting, to sharpen their focus, and it challenges all of us to craft better and more complete responses to better questions. It suggests that, with or without the hyphen, the world system project remains vibrant.

\section{References}

Abu-Lughod, Janet. 1989. Before European Hegemon: The World System A.D. 1250-1350. New York: Oxford University Press.

Amin, Samir. 1999. "History Conceived as an Eternal Cycle." Review 22(3): 291-326.

Arrighi, Giovanni. 1999. "The World According to Andre Gunder Frank." Review 22(3): $327-$ 354.

Bergesen, Albert. 2015. "World-System Theory After Andre Gunder Frank," Journal of WorldSystems Research XXX.

Brenner, Robert. 1977. "The Origins of Capitalist Development: A Critique of Neo-Smithian Marxism." New Left Review 104: 25-92.

Chew, Sing. 2007. The Recurring Dark Ages: Ecological Stress, Climate Changes, and System Transformation. Lanham: AltaMira Press.

Davis, Mike. 2001. Late Victorian Holocausts: El Nino Famines and the Making of the Third World. London: Verso.

Denemark, Robert. 1999. "World System History: From Traditional International Politics to the Study of Global Relations." International Studies Review 1(2): 43-75.

Denemark, Robert, Jonathan Friedman, Barry K. Gills, and George Modelski, eds. 2000. World System History: The Social Science of Long-Term Change. London: Routledge.

Frank, Andre Gunder. 1979. Dependent Accumulation and Underdevelopment. New York: Monthly Review Press.

-------. 2005. ReOrient: Global Economy in the Asian Age. Los Angeles: University of California Press.

-------. 2014. ReOrienting the 19th Century: Global Economy in the Continuing Asian Age. Boulder CO: Paradigm.

Frank, Andre Gunder and Barry K. Gills. 1993. The World System: Five Hundred Years or Five Thousand? London: Routledge. 
Gills, Barry K. and Andre Gunder Frank 1990. "The Cumulation of Accumulation: Theses and Research Agenda for Five Thousand Years of World System History.” Dialectical Anthropology 15: 19-42.

Hornborg, Alf. 2001. The Power of the Machine. Walnut Creek CA: AltaMira Press.

Modelski, George and William R. Thompson. 1996. Leading Sectors and World Powers: The Coevolution of Global Politics and Economics. Columbia SC: University of South Carolina Press.

Odone, Cristina. 2013. “Is Pope Francis a Socialist?” Newsweek, December 13.

Pollins, Brian. 1996. "Global Political Order, Economic Change, and Armed Conflict: Coevolving Systems and the Use of Force." American Political Science Review 90: 103117.

Sugihara, Kaoru. 1996. "The European Miracle and the East Asian Miracle: Towards a New Global Economic History." Osaka University Economic Review 12: 27-48.

Wallerstein, Immanuel. 1999. "Frank Proves the European Miracle.” Review 22(3): 355-71. 